\title{
Effect of use of the enzymes on the quality of pan bread made from Egyptian wheat flour
}

\author{
Abd-Elrahman, M.G*; El-Desouky, A.I.*; Ghazal, G.I.A.*; Mohamed, M.H.*andAbd El-Salam, A.M.** \\ * Food Technology, Fac. of Agric. Moshtohor, Benha Univ., Egypt. \\ ** Food Technology Research Institute, Agricultural Research Center, Giza, Egypt. \\ Corresponding author : mohamed.ghamry@fagr.bu.edu.eg
}

\begin{abstract}
The aim of this study is toevaluate the effect of some microbial enzymessuch as Xylanase (XY), glucose oxidase (GO) and $\alpha$ amylase (AM) to improve quality aspects, sensory attributes and rheological properties of pan bread produced from commercial wheat flour ( $82 \%$ ext.). The three enzymes were added by three doses. XY and GO added at 10,15 and $20 \mathrm{ppm}$, While AM was added at 5,10 and15 ppm. The obtained data revealed that the enzymes have been given a marked improvement todough characters and bread quality. Specific volumewas increased with XYby3.5, 3.7 and 3.8\%, and by 2.9, 2.9and 3.2 for AM, while it was by 3.1, 3.0 and 3.6 for GO respectively.Compared with a control sample. The staling of breadwas decreasedwith theadding of these enzymes, this decrease was linear with increase the doses of enzymes alike. Adding of any doses of any enzymes had apositive effect of the bread texture profile and this effect were linear, which showeda decreasein the firmness, gamenessand resilience, whilethe cohesiveness, chewiness, and springiness characteristics was decreased, this refers to increase of softness and chewness of bread. Also, this improving was maintained alveogram.
\end{abstract}

Keywords: Enzymes, Egyptian wheat flour, Alveogragh, Bread staling.

\section{Introduction}

The bread is one of the major components of the human diet in most parts of the world.In the recent years a lot of studies focused on the use of many enzymes to improve quality of bakery products and overcome some of the problems. These include gluten-crosslinking enzymes such as (transglutaminase, glucose oxidase and laccase) and polysaccharide and gluten degrading enzymes such as (alpha-amylase, xylanase and protease). For both of them the role and impact, Where all of them affected significantly to viscoelastic properties of dough glucose oxidase and laccase give the results to the contrary. Transglutaminase is impact positively on strengthening of gluten network(Caballero et al., 2007). Microbial glucose oxidase (EC 1.1.2.3.4) is currently receiving much attention due to its wide applications in chemical, pharmaceutical, food, beverage, clinical chemistry, biotechnology and other industries (Aja et al., 2003; Bankar et al., 2009). Different GO concentrate was used to improve the dough quality (Bonet et al., 2006; Dagdelen and Gocmen 2007; Steffolani et al., 2010; Decamps et al., 2012; Shafisoltani et al., 2014)

The addition of xylanase (EC 3.2.1.8) on the wheat flour produced significant changes on dough rheology and bread quality character(Mariotti et al., 2013). $X Y$ contribute to the improvement of the technological characteristics of bread made from white wheat flour and whole grain wheat flour. The dosage of $8 \mathrm{~g} \mathrm{XY}$ per 100 kgflour yielded higher specific volume and lower firmness (Jaekel et al.,
2012). Allot of studedes are used $X Y$ by different concentrates to improving dough (Collins et al., 2006; Jaekel et al., 2012; Ahmad et al., 2013)

$\alpha$-Amylase (EC 3.2.1.1) is an endo-hydrolase belonging to the glycoside hydrolase 13 family and is considered to be one of the primary enzymes responsible for starch degradation (Majzlova et al., 2013). In wheat, starch makes up over $70 \%$ of total grain dry weight and is made of glucose residues linked by $\alpha-1,4$ glucosidic bonds and branched via $\alpha$ -1,6 glucosidic linkages (Ball and Morell, 2003). Giannone et al. (2016)reported that the evolution of textural properties, crumb moisture, and $\mathrm{a}_{\mathrm{w}}$ during bread storage confirmed that AM are effective in slowing down bread staling. The significantly greater effect provided by the $\alpha$-amylase-lipase combination, that positively modified textural and crumb grain properties of bread.

The aim of the present work has been to evaluate effect of different enzymes doses on the properties of wheat flour dough and final product quality. The effect of these different doses on the rheological properties, sensory evaluation and bread quality were evaluated.

\section{Materials and methods}

Commercial wheat flour obtained from East of Cairo Mills (Ministry of Supply \& Internal Trade). All microbial enzymes are obtained from Sigma Chemical Company (Saint Louis, USA). The flour was stored in a cool atmosphere pending the analysis and manufacturing. Enzymes were stored in a cool 
atmosphere and frozen condition which goes along with attached data with the enzyme (xylanase at $8^{\circ} \mathrm{C}$ ) and(glucose oxidase and $\alpha$ amylase at $-20^{\circ} \mathrm{C}$.).
The straight dough method for pan bread production was carried out according to the method described by (AACC, 2000)as described in Table (I).

\section{Processing of Pan Bread}

Table I. Component of pan bread blends.

\begin{tabular}{ccccccccc}
\hline Treatment & $\begin{array}{c}\text { Flour } \\
(\mathrm{g})\end{array}$ & $\begin{array}{c}\text { Salt } \\
(\mathrm{g})\end{array}$ & $\begin{array}{c}\text { Yeast } \\
(\mathrm{g})\end{array}$ & $\begin{array}{c}\text { Sugar } \\
(\mathrm{g})\end{array}$ & $\begin{array}{c}\text { Corn oil } \\
(\mathrm{g})\end{array}$ & $\begin{array}{c}\text { GO } \\
(\mathbf{p p m})\end{array}$ & $\begin{array}{c}\text { XY } \\
(\mathbf{p p m})\end{array}$ & $\begin{array}{c}\text { AM } \\
(\mathbf{p p m})\end{array}$ \\
\hline Control & 100 & 1.0 & 1.5 & 1.5 & 1.5 & - & - & - \\
T1 & 100 & 1.0 & 1.5 & 1.5 & 1.5 & 10 & - & - \\
T2 & 100 & 1.0 & 1.5 & 1.5 & 1.5 & 15 & - & - \\
T3 & 100 & 1.0 & 1.5 & 1.5 & 1.5 & 20 & - & - \\
T4 & 100 & 1.0 & 1.5 & 1.5 & 1.5 & - & 10 & - \\
T5 & 100 & 1.0 & 1.5 & 1.5 & 1.5 & - & 15 & - \\
T6 & 100 & 1.0 & 1.5 & 1.5 & 1.5 & - & 20 & - \\
T7 & 100 & 1.0 & 1.5 & 1.5 & 1.5 & - & - & 5 \\
T8 & 100 & 1.0 & 1.5 & 1.5 & 1.5 & - & - & 10 \\
T9 & 100 & 1.0 & 1.5 & 1.5 & 1.5 & - & - & 15 \\
\hline
\end{tabular}

The ingredients were mixed thoroughly by hand for one minute, then the dough was further mixed in a laboratory mixer for approximately four minutes. The dough was put into a greased fermentation bowl, and then cut, rolled and placed in a fermentation cabinet for 50 minutes at $37 \pm 2{ }^{\circ} \mathrm{C}$ and $80-85 \%$ relative humidity. Then baked in an electric oven at about $220 \pm 8^{\circ} \mathrm{C}$ for 25 minutes. After baking loaves were separated from the metal pan and allowed to cool at room temperature before organoleptic evaluation. The produced pan bread were measured each of weight, volume and chemical composition.

\section{Analytical methods}

Moisture, protein, ash, total fat and fibercontents were determined according to (AOAC, 2000). Available carbohydrates were calculated by difference.

\section{Rheological properties (Alveograph)}

The Alveograph characteristics of wheat flour were determined in a Chopin NG Alveograph according to (AACC 2000)Method 54-30.02. The Alveograph parameters were automatically recorded by Chopin Alveolink-NG software, including the maximum overpressure or tenacity $(P)$ needed to blow the dough bubble, the abscissa at rupture $(L)$ measuring dough extensibility, the index of swelling $(G)$ (measured as the square root of the volume of air necessary to inflate the dough bubble until it ruptures), the deformation energy of dough $(W)$ representing the energy necessary to inflate the dough bubble to the point of rupture, the deformation curve $(P / L)$ and the elasticity index $(I e)$.

\section{Pan bread characteristics: Specific volume:}

Specific volume was determined by Alfalfaseed displacement method (AACC 2000)and calculated as the ratio $\mathrm{cm}^{3} / \mathrm{g}$. Specific volume determination was carried out one hour after leaving the oven in triplicate.

\section{Alkaline water retention capacity:}

Alkaline water retention capacity was determinated according to the method of (Yamazaki, 1953), as modified by (Kitterman and Rubenthaler, 1971). To lg ofpan bread sample [test tube weighed with dry sample $(w 1)], 5 \mathrm{ml}$ of $0.1 \mathrm{~N}$ $\mathrm{NaHCO}_{3}$ was added and mixed for 30 set in a VariWhirl mixer. The samples were then allowed to stand at room temperature $\left(21^{\circ} \mathrm{C}\right)$ for $20 \mathrm{~min}$, centrifuged (2000 rpm, $15 \mathrm{~min}$ ), and drained for $10 \mathrm{~min}$ at an angle of $10-15^{\circ}$, with the horizontal. Test tubes with their contents were then weighed (w2), and the alkaline water retention capacity was calculated as follows:

$$
\frac{\text { Alkaline water retention capacity }(\mathrm{g})}{\mathrm{g} \text { sample }}=w 2-w 1
$$

Tixture analyser (Firmness and springiness):

Crumb firmness was determined using AACC method 74-09.01, and an adaption of this method used to determine springiness according to (Sangnark and Noomhorm, 2004). The analyses were carried out using a TA-XT2 texturometer with a $25 \mathrm{~kg}$ load (stable Micro Systems, Surrey, England) with the $\mathrm{p} / 25$ cylindrical aluminium sensor probe. The parameters established were: test option and mode $=$ measurement of the compression force, hold until time, pretest speed $=10 \mathrm{~mm} / \mathrm{s}$, test speed $=1.7$ $\mathrm{mm} / \mathrm{s}$, posttest speed $=10 \mathrm{~mm} / \mathrm{s}$, distance $=40 \%$, time $=60 \mathrm{~s}$ and auto trigger $=10 \mathrm{~g}$. Fourteen replicates were carried out for each trial.

\section{Sensory evaluation}

Sensory evaluation of enzymes-supplemented and control bread was carried out by an expert panel of nine judges according to the 100-point evaluation scheme given by (Pyler, 1988) and make some adjustments. The maximum scores of bread 
characteristics were: volume (10); shape fitness (10); appearnce (10); color of crust (5); color of crumb (5); cell uniformity (10); moistness (10); chewiness (10);freshness (10); flavor andaroma (10); taste (10) and overall acceptability (100).

\section{Statistical analysis}

The statistical analysis was carried out using ANOVA with two factors under significance level of 0.05 for the whole results using SPSS (ver. 22). Data were treated as a complete randomization design according toSteel $\boldsymbol{e t}$ al. (1997).Multiple comparisons were carried out applying LSD.

\section{Results and Discussion}

Approximate chemical composition of flour

Approximate chemical composition of Egyptian commercial flour (82\% extract) was shown in Table (1). Commercial flour, followed the types of wheat, which is characterized as a medium strength. That is through a chemical composition (protein content) It does not express truthfully, protein quality (wet and dry gluten) and rheological properties of this flour (alveograph parameters) (Bell, 1990 andIndrani et al., 2007).

Table 1. Chemical composition of commercial flour (82\% ext.).

\begin{tabular}{ccccccccc}
\hline Material & Moisture & Protein* & Fat* & Ash* & Fiber* & $\begin{array}{c}\text { Available } \\
\text { carbohydrate } \\
*\end{array}$ & $\begin{array}{c}\text { Wet } \\
\text { gluten }\end{array}$ & $\begin{array}{c}\text { Dry } \\
\text { gluten }\end{array}$ \\
\hline \multirow{2}{*}{ Wheat flour } & $\mathbf{1 4 . 2 0}$ & $\mathbf{1 2 . 9 2}$ & $\mathbf{1 . 6 9}$ & $\mathbf{1 . 3 9}$ & $\mathbf{2 . 5 3}$ & $\mathbf{8 1 . 4 7}$ & $\mathbf{2 8 . 6}$ & $\mathbf{1 1 . 2}$ \\
\hline $\mathbf{0 . 1 2}$ & $\pm \mathbf{0 . 1 5}$ & $\pm \mathbf{0 . 0 1}$ & $\pm \mathbf{0 . 1 0}$ & $\pm \mathbf{0 . 1 7}$ & $\pm \mathbf{0 . 2 8}$ & $\pm \mathbf{0 . 1 4}$ & \pm 0.25 \\
\hline
\end{tabular}

* on dry weight basis.

Chemical composition of pan bread

The results indicated that no significant difference between treatments in the same composite (protein, fat), only a very slight degree, with the exception of a slight difference. Some composition explained lower on some treatments such as moisture, ash and carbohydrates(Table.2).

Table 2. Chemical composition of pan bread

\begin{tabular}{|c|c|c|c|c|c|}
\hline Treatment & Moisture & Protein & Fat & Ash & $\begin{array}{c}\text { Total } \\
\text { carbohydrates }\end{array}$ \\
\hline Control & $31.09 \pm 0.33^{b}$ & $12.77 \pm 0.27^{a}$ & $3.17 \pm 0.14^{a}$ & $1.69 \pm 0.04^{b}$ & $82.37 \pm 0.35^{a b}$ \\
\hline T1 & $30.21 \pm 0.22^{\mathrm{de}}$ & $12.56 \pm 1.60^{a}$ & $3.20 \pm 0.13^{\mathrm{a}}$ & $1.63 \pm 0.01^{b}$ & $83.01 \pm 1.67^{a b}$ \\
\hline $\mathbf{T 2}$ & $25.91 \pm 0.17^{\mathrm{g}}$ & $11.65 \pm 1.10^{a}$ & $3.15 \pm 0.08^{a}$ & $1.93 \pm 0.02^{\mathrm{ab}}$ & $83.88 \pm 1.15^{a}$ \\
\hline T3 & $30.91 \pm 0.32^{\mathrm{bc}}$ & $12.46 \pm 0.35^{a}$ & $2.96 \pm 0.30^{\mathrm{a}}$ & $2.13 \pm 0.02^{\mathrm{a}}$ & $82.25 \pm 0.09^{a b}$ \\
\hline T4 & $31.64 \pm 0.22^{a}$ & $12.78 \pm 0.40^{\mathrm{a}}$ & $2.92 \pm 0.28^{\mathrm{a}}$ & $2.28 \pm 0.50^{\mathrm{a}}$ & $82.03 \pm 0.62^{\mathrm{ab}}$ \\
\hline T5 & $28.61 \pm 0.11^{f}$ & $12.86 \pm 0.07^{a}$ & $3.11 \pm 0.28^{\mathrm{a}}$ & $2.03 \pm 0.02^{a b}$ & $82.01 \pm 0.28^{a b}$ \\
\hline T6 & $30.81 \pm 0.05^{c}$ & $12.00 \pm 0.91^{a}$ & $2.18 \pm 0.22^{\mathrm{a}}$ & $2.31 \pm 0.02^{a}$ & $82.88 \pm 0.05^{a b}$ \\
\hline T7 & $31.14 \pm 0.11^{b}$ & $12.74 \pm 0.4^{a}$ & $3.01 \pm 0.90^{\mathrm{a}}$ & $2.14 \pm 0.02^{a}$ & $82.11 \pm 0.41^{a b}$ \\
\hline T8 & $29.83 \pm 0.07^{e}$ & $12.86 \pm 0.37^{a}$ & $3.15 \pm 0.09^{a}$ & $2.21 \pm 0.02^{\mathrm{a}}$ & $81.77 \pm 0.46^{b}$ \\
\hline T9 & $31.34 \pm 0.18^{a b}$ & $12.98 \pm 0.27^{a}$ & $3.33 \pm 0.20^{\mathrm{a}}$ & $2.01 \pm 0.03^{\mathrm{ab}}$ & $81.69 \pm 0.10^{b}$ \\
\hline LSD & 0.48 & 1.74 & 0.47 & 0.38 & 1.89 \\
\hline
\end{tabular}

Means with the same latter in the same column are not significant different $(p>0.05)$.
T1: $10 \mathrm{ppm}$ GO
T2: 15 ppm GO
T3: 20 ppm GO
T4: $10 \mathrm{ppm}$ XY
T5: $15 \mathrm{ppm} X Y$
T6: $20 \mathrm{ppm} \mathrm{XY}$
T7: 5 ppm AM
T8: $10 \mathrm{ppm}$ AM
T9: 15 ppm AM

Effect of enzymes on bread properties Freshness of pan bread
Alkaline water retention capacity (AWRC) is a simple and quick test to follow staling of bread. Higher values of AWRC mean higher freshness of 
bread (Yaseen et al., 2010). It's clear that the addition of enzymes improved the staling and degree of freshness of pan bread (fig. 1). Results showed that the all treatmentswith all enzymes are showed marked improvement in the freshness of bread. All enzymes indicate the positive linear improving of bread staling with increasing the dose of the enzyme. These results are in agreement with Caballero et al.(2007) andKatina et al. (2006). They reported that a lot of enzymes such as XY, AMand GO can improve the bread quality (freshness or staling). For each of these enzymes behave in a special attitude towards this improvement. XL and AM enzymescould lead the positive effect on bread staling throw increasing of the monosaccharide and increase the bread ability to retain water. GO lead to increasing the molecular weight of gluten network.

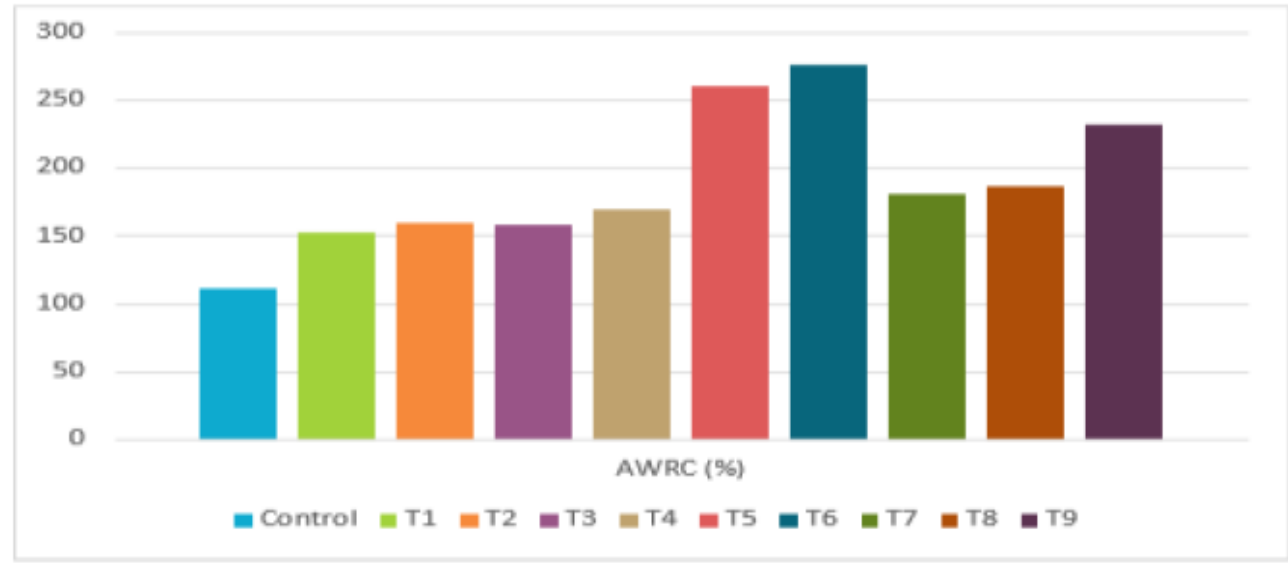

Fig. 1. Alkaline water retention capacity (AWRC) for bread treatments.

\section{Sensory evaluation of pan bread}

Data in Table (3) and Fig (2) indicated that the significant differences between doses in the same treatments. The obtained data indicate that treatments are giving $\operatorname{marked}(p \leq 0.05)$ improvement in all attributes compared with control samples.On the contrary, control sample was recorded lower value with most of attributes. These it may be due to the characters of Egyptian commercial flour (82\% ext.) include protein content and protein strength. Enzymes addition showed the effect significantly on attributes of pan bread and these effects was gradually increase with increase the doses of enzymes (Ahmad et al., 2014 andYang et al., 2014).

The relation between sensory evaluation and freshness of pan bread it has been clarified through response surface plots as in $\mathbf{F i g ( 3 )}$. Through the figure illustrated as follows: There is a linear relationship between doses of $\mathrm{XY}$ and values of AWRC. But,the relation between doses of XY and sensory evaluation was a vacillating (Shah et al., 2006). There are also the same as the relationship between AM or GO with AWRCand sensory evaluation with a different amount of linear increase. AM showed a linear positive effect stable on AWRCand non-linear relationship with sensory evaluation.GO clarified a linear relationship with AWRC and achieve the highest value ofsensory evaluation at medium dose (Caballero et al., 2007).

\section{Texture profile analysis}

Experimental responses of bread properties are presented in Table (4) as well as compared toSpecific volume as in Fig 4. The hardness is a measure of the resistance of bread to deformation. The highest level of hardness was detected in control bread (without enzymes) which indicates a low degree of softness and crispness. A gradual decrease in hardness was observed when XY or AM doses were increased. Low levels of hardness was detected with high doses of AM and XY treatments. The AM negative effect could be due to the increase in starch hydrolysis by enzyme action, consequently increasing the gas production by yeast added. The negative effect of $\mathrm{XY}$ on dough hardness could be due to thehydrolysis of water insoluble pentosans (Leon et al., 2002 andShah et al., 2006). The both of enzymes have a positive effect on bread softness. These results is in agreement with (Ahmad et al., 2013 and Driss $\boldsymbol{e t}$ al., 2013). On the contrary, GO had a linear positive effect on bread hardness, the higher value of the hardness it was with the highest doses of GO. This result is in agreement with (Steffolani $\boldsymbol{e t}$ al., 2010) .who observed that GO is one of oxidative enzymes which when added to wheat dough The oxidant action of the enzyme led to a cross-link among proteins through disulfide and non-disulfide bonds (high molecular weight glutenin). This undoubtedly is reflected on both the dough strength and bread resistant to extension. These effects are associated with the doses of the enzymes. It could be concluded that the highest improve of all texture parameters was deted in the commercial wheat treated with 20 ppm Go. Followed by the treated with 20 ppm XY and finally that treated with $15 \mathrm{ppm}$ AM. 


\begin{tabular}{|c|c|c|c|c|c|c|c|c|c|c|c|c|}
\hline \multirow[t]{3}{*}{ Sample } & \multicolumn{12}{|c|}{ Organolyptic attributes } \\
\hline & \multirow{2}{*}{$\begin{array}{l}\text { Volume } \\
\text { (10) }\end{array}$} & \multirow{2}{*}{$\begin{array}{c}\text { Shape } \\
\text { fitness } \\
(10)\end{array}$} & \multirow{2}{*}{$\begin{array}{c}\text { Appearance } \\
(10)\end{array}$} & \multicolumn{2}{|c|}{ color } & \multicolumn{4}{|c|}{ Texture } & \multirow{2}{*}{$\begin{array}{c}\text { Flavor } \\
\& \\
\text { aroma } \\
(10)\end{array}$} & \multirow{2}{*}{$\begin{array}{l}\text { Taste } \\
(10)\end{array}$} & \multirow{2}{*}{$\begin{array}{c}\text { Overall } \\
\text { acceptability } \\
(\mathbf{1 0 0})\end{array}$} \\
\hline & & & & Crumb & $\begin{array}{c}\text { Crust } \\
(5)\end{array}$ & $\begin{array}{c}\text { Cell } \\
\text { uniformity } \\
(10)\end{array}$ & $\begin{array}{l}\text { Moistness } \\
\text { (10) }\end{array}$ & $\begin{array}{c}\text { Chewiness } \\
\text { (10) }\end{array}$ & $\begin{array}{c}\text { Freshness } \\
\text { (10) }\end{array}$ & & & \\
\hline control & $\begin{array}{c}6.89 \\
\pm 0.26^{c}\end{array}$ & $\begin{array}{c}7.44 \\
\pm 0.38^{\mathrm{ab}}\end{array}$ & $\begin{array}{c}7.00 \\
\pm 0.29^{b}\end{array}$ & $\begin{array}{c}3.67 \\
\pm 0.17^{\mathrm{a}}\end{array}$ & $\begin{array}{c}3.78 \\
\pm 0.22^{\mathrm{a}}\end{array}$ & $\begin{array}{c}7.44 \\
\pm 0.38^{\text {ab }}\end{array}$ & $\begin{array}{c}7.56 \\
\pm 0.29^{a b}\end{array}$ & $\begin{array}{c}8.00 \\
\pm 0.44^{\mathrm{a}}\end{array}$ & $\begin{array}{c}7.44 \\
\pm 0.24^{\text {ab }}\end{array}$ & $\begin{array}{c}7.44 \\
\pm 0.41^{\text {ab }}\end{array}$ & $\begin{array}{c}7.89 \\
\pm 0.35^{\text {ab }}\end{array}$ & $\begin{array}{c}\mathbf{7 9 . 3 3} \\
\pm 3.82^{\text {ab }}\end{array}$ \\
\hline GO 1 & $\begin{array}{c}7.78 \\
\pm 0.28^{b}\end{array}$ & $\begin{array}{c}7.44 \\
\pm 0.29^{\mathrm{ab}}\end{array}$ & $\begin{array}{c}7.67 \\
\pm 0.33^{a}\end{array}$ & $\begin{array}{c}4.11 \\
\pm 0.2^{\mathrm{a}}\end{array}$ & $\begin{array}{c}3.89 \\
\pm 0.11^{\mathrm{a}}\end{array}$ & $\begin{array}{c}7.44 \\
\pm 0.24^{\text {ab }}\end{array}$ & $\begin{array}{c}7.56 \\
\pm 0.24^{\text {ab }}\end{array}$ & $\begin{array}{c}7.11 \\
\pm 0.35^{\text {ab }}\end{array}$ & $\begin{array}{c}7.33 \\
\pm 0.24^{\text {ab }}\end{array}$ & $\begin{array}{c}7.44 \\
\pm 0.34^{\text {ab }}\end{array}$ & $\begin{array}{c}7.67 \\
\pm 0.17^{\text {ab }}\end{array}$ & $\begin{array}{c}77.67 \\
\pm 3.5^{\text {ab }}\end{array}$ \\
\hline GO 2 & $\begin{array}{c}7.67 \\
\pm 0.17^{b}\end{array}$ & $\begin{array}{c}7.11 \\
\pm 0.2^{\mathrm{ab}}\end{array}$ & $\begin{array}{c}7.78 \\
\pm 0.32^{\mathrm{a}}\end{array}$ & $\begin{array}{c}4.00 \\
\pm 0.29^{\mathrm{a}}\end{array}$ & $\begin{array}{c}3.89 \\
\pm 0.31^{\mathrm{a}}\end{array}$ & $\begin{array}{c}7.11 \\
\pm 0.26^{b}\end{array}$ & $\begin{array}{c}7.67 \\
\pm 0.17^{\text {ab }}\end{array}$ & $\begin{array}{c}6.89 \\
\pm 0.42^{b}\end{array}$ & $\begin{array}{c}7.22 \\
\pm 0.36^{\text {ab }}\end{array}$ & $\begin{array}{c}7.67 \\
\pm 0.37^{\mathrm{a}}\end{array}$ & $\begin{array}{c}7.78 \\
\pm 0.36^{\text {ab }}\end{array}$ & $\begin{array}{c}76.89 \\
\pm 2.43^{\text {ab }}\end{array}$ \\
\hline GO 3 & $\begin{array}{c}9.0 \\
\pm 0.24^{\mathrm{a}}\end{array}$ & $\begin{array}{c}7.67 \\
\pm 0.33^{a}\end{array}$ & $\begin{array}{c}8.44 \\
\pm 0.18^{a}\end{array}$ & $\begin{array}{c}4.11 \\
\pm 0.35^{\mathrm{a}}\end{array}$ & $\begin{array}{c}3.78 \\
\pm 0.28^{a}\end{array}$ & $\begin{array}{c}6.67 \\
\pm 0.24^{b}\end{array}$ & $\begin{array}{c}8.11 \\
\pm 0.26^{a b}\end{array}$ & $\begin{array}{c}7.44 \\
\pm 0.47^{\text {ab }}\end{array}$ & $\begin{array}{c}7.89 \\
\pm 0.31^{\mathrm{a}}\end{array}$ & $\begin{array}{c}7.67 \\
\pm 0.41^{\mathrm{a}}\end{array}$ & $\begin{array}{c}8.11 \\
\pm 0.26^{a}\end{array}$ & $\begin{array}{c}82.44 \\
\pm 1.86^{\mathrm{a}}\end{array}$ \\
\hline XY 1 & $\begin{array}{c}7.44 \\
\pm 0.29^{\mathrm{bc}}\end{array}$ & $\begin{array}{c}6.67 \\
\pm 0.41^{b}\end{array}$ & $\begin{array}{c}7.11 \\
\pm 0.39^{b}\end{array}$ & $\begin{array}{c}3.78 \\
\pm 0.32^{\mathrm{a}}\end{array}$ & $\begin{array}{c}4.11 \\
\pm 0.2^{\mathrm{a}}\end{array}$ & $\begin{array}{c}7.67 \\
\pm 0.29^{a}\end{array}$ & $\begin{array}{c}7.56 \\
\pm 0.29^{b}\end{array}$ & $\begin{array}{c}6.78 \\
\pm 0.52^{b}\end{array}$ & $\begin{array}{c}7.00 \\
\pm 0.29 \\
\end{array}$ & $\begin{array}{c}6.78 \\
\pm 0.32^{\text {ab }}\end{array}$ & $\begin{array}{c}6.89 \\
\pm 0.26^{b}\end{array}$ & $\begin{array}{c}74.44 \\
\pm 2.27^{\mathrm{b}}\end{array}$ \\
\hline XY 2 & $\begin{array}{c}7.89 \\
\pm 0.31^{b}\end{array}$ & $\begin{array}{c}7.44 \\
\pm 0.29^{\mathrm{ab}}\end{array}$ & $\begin{array}{c}7.56 \\
\pm 0.24^{b}\end{array}$ & $\begin{array}{c}3.67 \\
\pm 0.29^{a}\end{array}$ & $\begin{array}{c}4.22 \\
\pm 0.15^{\mathrm{a}}\end{array}$ & $\begin{array}{c}7.33 \\
\pm 0.29^{\text {ab }}\end{array}$ & $\begin{array}{c}7.78 \\
\pm 0.22^{\text {ab }}\end{array}$ & $\begin{array}{c}7.67 \\
\pm 0.37^{\text {ab }}\end{array}$ & $\begin{array}{c}7.67 \\
\pm 0.29 \mathrm{ab}\end{array}$ & $\begin{array}{c}7.67 \\
\pm 0.29^{\mathrm{a}}\end{array}$ & $\begin{array}{c}7.22 \\
\pm 0.28^{b}\end{array}$ & $\begin{array}{c}75.67 \\
\pm 2.8^{\text {ab }}\end{array}$ \\
\hline XY 3 & $\begin{array}{c}8.89 \\
\pm 0.26^{a}\end{array}$ & $\begin{array}{c}7.11 \\
\pm 0.39^{\mathrm{ab}}\end{array}$ & $\begin{array}{c}8.11 \\
\pm 0.2^{\mathrm{ab}}\end{array}$ & $\begin{array}{c}4.22 \\
\pm 0.15^{\mathrm{a}}\end{array}$ & $\begin{array}{c}4.33 \\
\pm 0.24^{\mathrm{a}}\end{array}$ & $\begin{array}{c}7.56 \\
\pm 0.18^{\text {ab }}\end{array}$ & $\begin{array}{c}8.33 \\
\pm 0.17^{a}\end{array}$ & $\begin{array}{c}7.33 \\
\pm 0.24^{\text {ab }}\end{array}$ & $\begin{array}{c}7.67 \\
\pm 0.24^{\text {ab }}\end{array}$ & $\begin{array}{c}7.00 \\
\pm 0.17^{\text {ab }}\end{array}$ & $\begin{array}{c}8.11 \\
\pm 0.26^{a}\end{array}$ & $\begin{array}{c}78.78 \\
\pm 1.61^{\text {ab }}\end{array}$ \\
\hline AM1 & $\begin{array}{c}7.33 \\
\pm 0.33^{\text {bc }} \\
\end{array}$ & $\begin{array}{c}7.67 \\
\pm 0.24^{\mathrm{a}} \\
\end{array}$ & $\begin{array}{c}7.33 \\
\pm 0.17^{\mathrm{b}} \\
\end{array}$ & $\begin{array}{c}4.00 \\
\pm 0.33^{a} \\
\end{array}$ & $\begin{array}{c}4.11 \\
\pm 0.26^{a} \\
\end{array}$ & $\begin{array}{c}6.33 \\
\pm 0.29^{c} \\
\end{array}$ & $\begin{array}{c}7.78 \\
\pm 0.32^{\text {ab }}\end{array}$ & $\begin{array}{c}6.33 \\
\pm 0.37^{b}\end{array}$ & $\begin{array}{c}7.33 \\
\pm 0.29^{\mathrm{ab}}\end{array}$ & $\begin{array}{c}6.67 \\
\pm 0.29^{b}\end{array}$ & $\begin{array}{c}6.67 \\
\pm 0.17^{b}\end{array}$ & $\begin{array}{r}71.89 \\
\pm 1.27^{b}\end{array}$ \\
\hline AM2 & $\begin{array}{c}7.44 \\
\pm 0.18^{\mathrm{bc}}\end{array}$ & $\begin{array}{c}6.56 \\
\pm 0.24^{b}\end{array}$ & $\begin{array}{c}7.22 \\
\pm 0.28^{b}\end{array}$ & $\begin{array}{c}3.89 \\
\pm 0.2^{\mathrm{a}}\end{array}$ & $\begin{array}{c}3.89 \\
\pm 0.26^{a}\end{array}$ & $\begin{array}{c}7.00 \\
\pm 0.17^{\mathrm{bc}}\end{array}$ & $\begin{array}{c}6.67 \\
\pm 0.24^{c}\end{array}$ & $\begin{array}{c}7.00 \\
\pm 0.33^{\text {ab }}\end{array}$ & $\begin{array}{c}6.56 \\
\pm 0.24^{b}\end{array}$ & $\begin{array}{c}6.67 \\
\pm 0.44^{b}\end{array}$ & $\begin{array}{c}7.33 \\
\pm 0.29^{\mathrm{ab}}\end{array}$ & $\begin{array}{c}71.56 \\
\pm 1.42^{b}\end{array}$ \\
\hline MA3 & $\begin{array}{c}8.67 \\
\pm 0.29^{a}\end{array}$ & $\begin{array}{c}6.89 \\
\pm 0.35^{\text {ab }}\end{array}$ & $\begin{array}{c}7.89 \\
\pm 0.26^{\text {ab }}\end{array}$ & $\begin{array}{c}3.89 \\
\pm 0.35^{a}\end{array}$ & $\begin{array}{c}4.11 \\
\pm 0.39^{\mathrm{a}}\end{array}$ & $\begin{array}{c}8.00 \\
\pm 0.24^{\mathrm{a}}\end{array}$ & $\begin{array}{c}8.00 \\
\pm 0.29^{a b}\end{array}$ & $\begin{array}{c}7.78 \\
\pm 0.22^{\text {ab }}\end{array}$ & $\begin{array}{c}7.11 \\
\pm 0.42^{\text {ab }}\end{array}$ & $\begin{array}{c}7.33 \\
\pm 0.37^{\mathrm{a}}\end{array}$ & $\begin{array}{c}7.78 \\
\pm 0.32^{\text {ab }}\end{array}$ & $\begin{array}{c}81.89 \\
\pm 2.13^{a}\end{array}$ \\
\hline LSD & 0.75 & 0.9 & 0.77 & 0.77 & 0.71 & 0.74 & 0.72 & 1.08 & 0.84 & 0.98 & 0.79 & 6.89 \\
\hline
\end{tabular}

Means with the same letter in the same column are not significant differences $(p>0.05)$. 

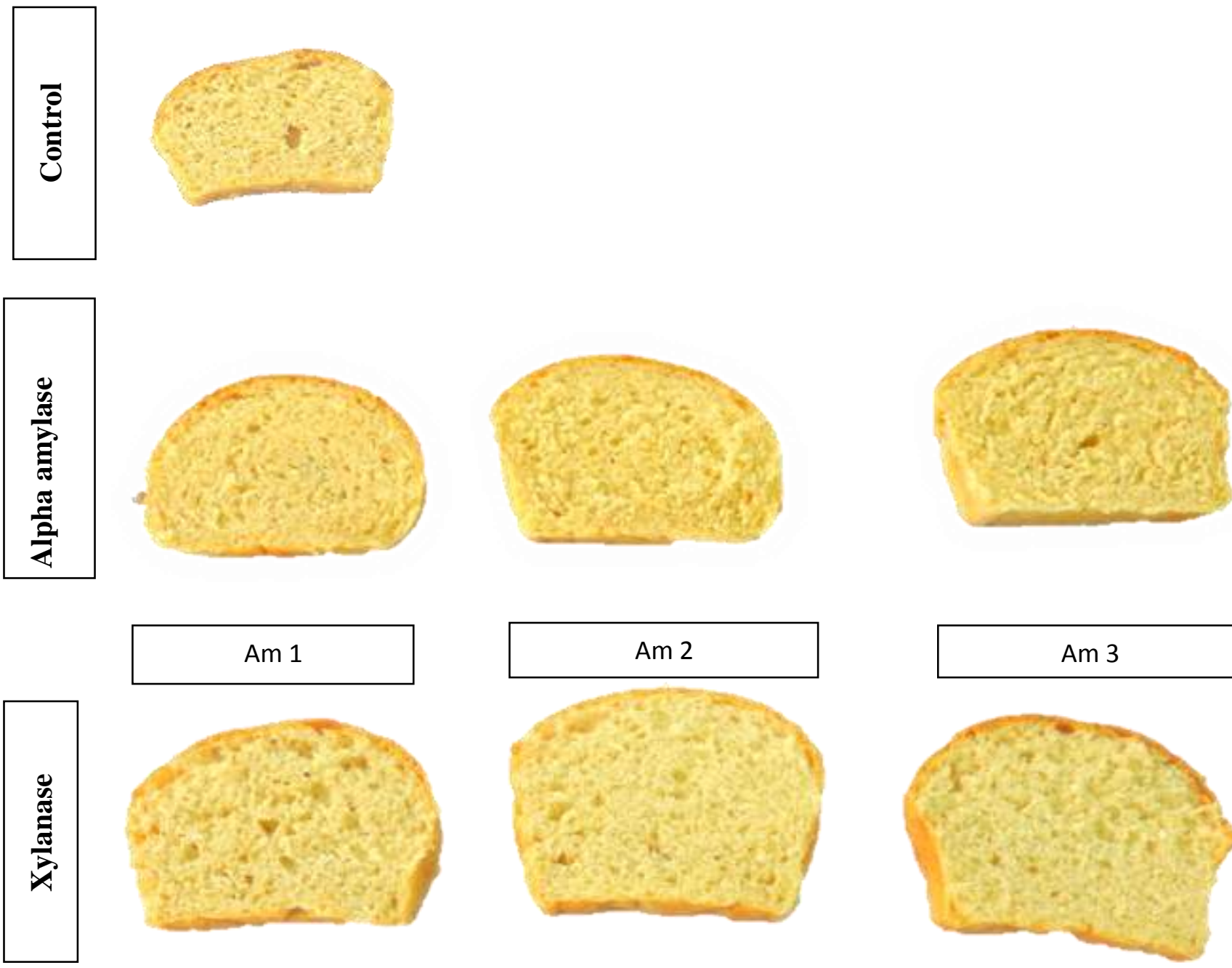

Am 3
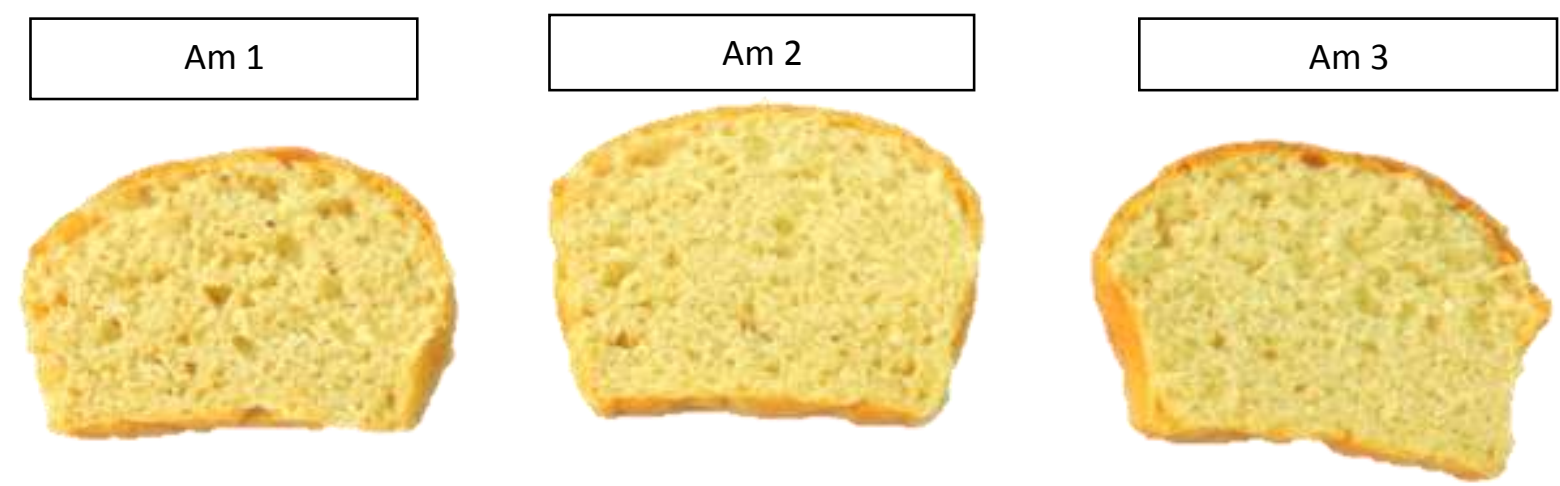

Ax 1
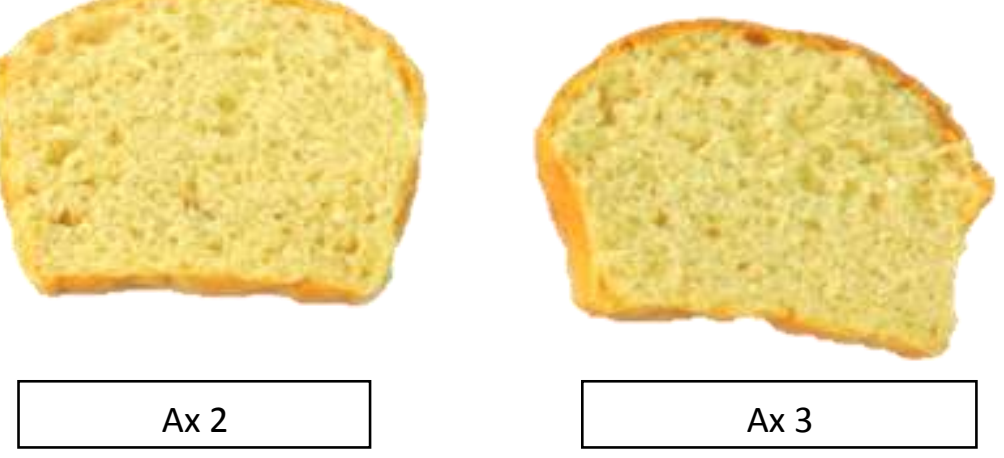

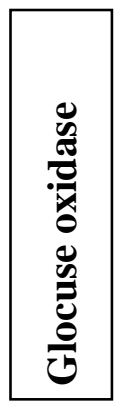
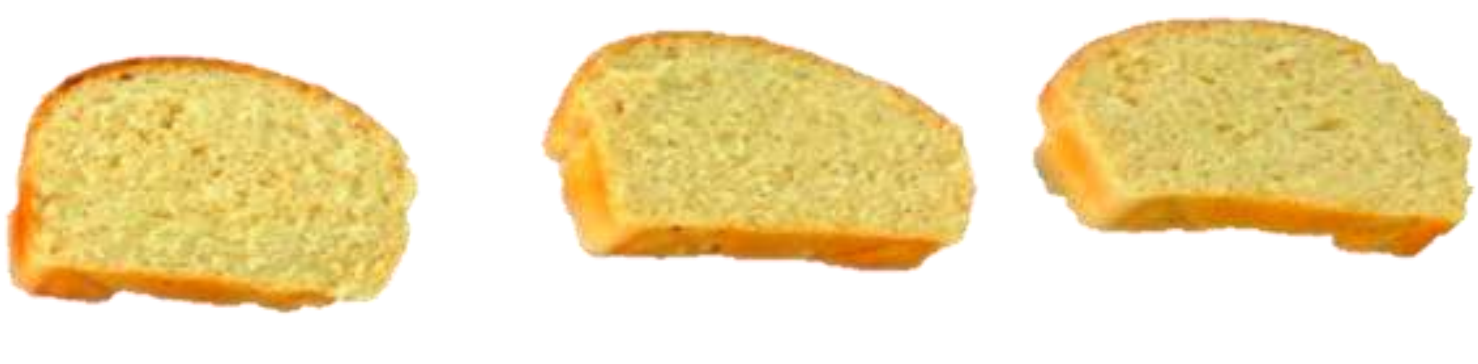

Gox 1

Gox 2

Gox 3

Fig. 2. Effects of different doses of enzymes on pan bread 


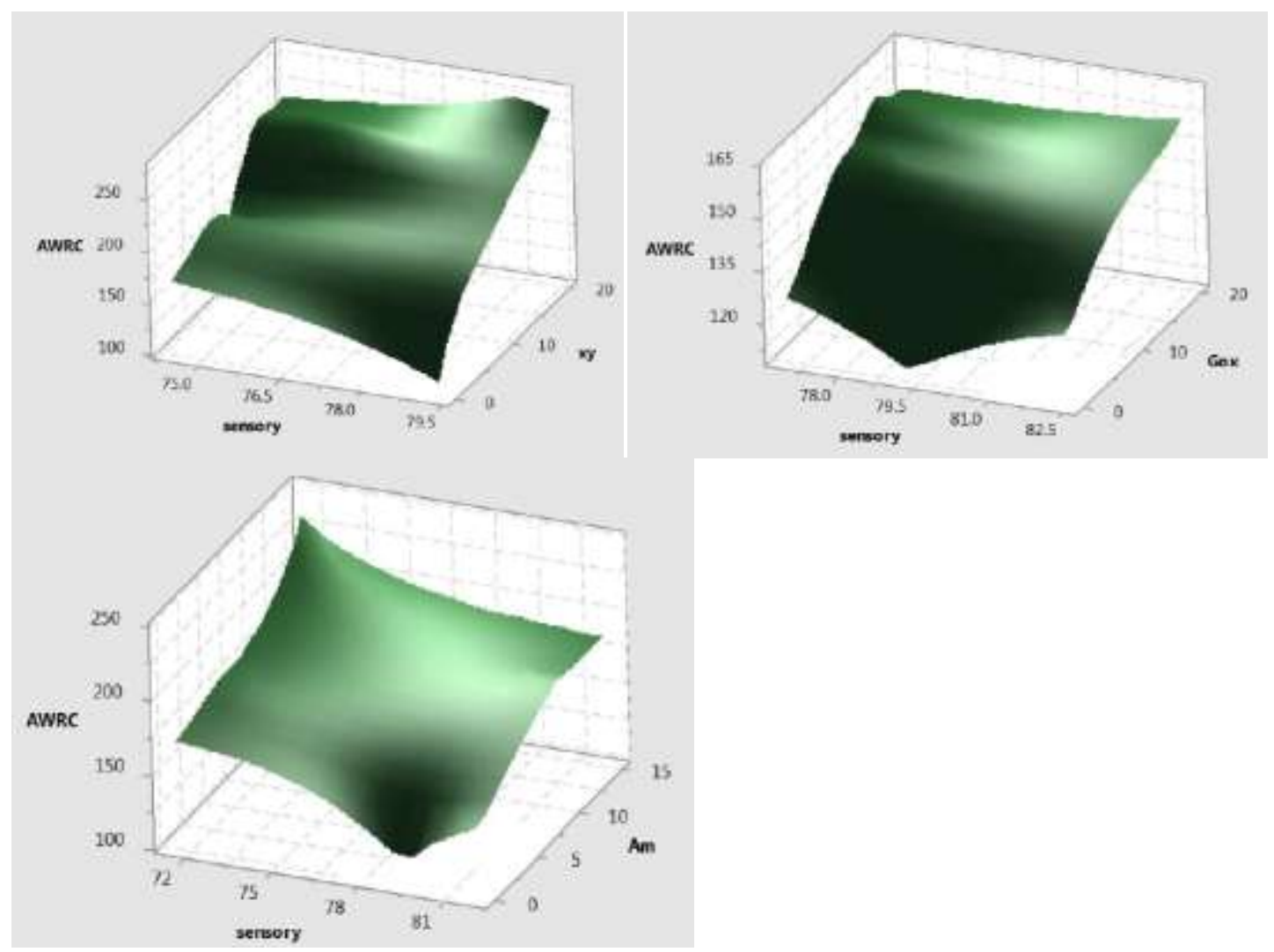

Fig.(3): Response surface plots of alkaline water retention capacity (AWRC) and sensory evaluation: GO, glucose oxidase; XY, xylanase; AM, $\alpha$ amylase.

Table 4. Texture profile analysis of pan bread

\begin{tabular}{ccccccc}
\hline \multirow{2}{*}{$\begin{array}{c}\text { Dosage of } \\
\text { enzymes }\end{array}$} & Firmness & Cohesiveness & Gumminess & Chewiness & Springiness & Resilience \\
\cline { 2 - 7 } Control & 9.470 & 0.127 & 2.470 & 1.536 & 0.822 & 0.353 \\
T1 & 4.900 & 0.670 & 3.498 & 2.758 & 0.788 & 0.269 \\
T2 & 3.580 & 0.693 & 2.481 & 1.926 & 0.776 & 0.453 \\
G3 & 5.200 & 0.714 & 3.486 & 1.987 & 0.570 & 0.314 \\
X1 & 3.480 & 0.395 & 1.374 & 0.626 & 0.455 & 0.155 \\
X2 & 6.620 & 0.555 & 3.676 & 2.656 & 0.723 & 0.460 \\
X3 & 2.450 & 0.565 & 1.392 & $\mathbf{0 . 7 2 9}$ & $\mathbf{0 . 5 2 4}$ & 0.305 \\
A1 & 3.820 & 0.494 & 1.888 & 0.912 & 0.483 & 0.398 \\
A2 & 4.810 & 0.510 & 2.454 & 1.470 & 0.603 & 0.236 \\
A3 & 2.990 & 0.496 & 1.483 & $\mathbf{0 . 6 8 6}$ & $\mathbf{0 . 4 6 2}$ & $\mathbf{0 . 3 0 2}$ \\
\hline
\end{tabular}

\section{Specific volume}

The effect of enzymes on specific volume of pan bread is presented in Table (5). Immediately after baking, pan bread specific volume increased significantly with increasing the doses of enzymes. The specific volume of bread loaves with any doses of all enzymes was significantly higher $(p<0.05)$ than the control sample $\left(2.01 \mathrm{~cm}^{3} / \mathrm{g}\right)$, and highest value it was for bread loaves treated with XY3 (3.80 $\left.\mathrm{cm}^{3} / \mathrm{g}\right)$, GO3 $\left(3.60 \mathrm{~cm}^{3} / \mathrm{g}\right)$ and Am3 $\left(3.24 \mathrm{~cm}^{3} / \mathrm{g}\right) . \mathrm{XY}$ had a linear positive effect on bread specific volume (Bonet et al., 2006 andSteffolani et al., 2010). The higher loaf volume could be due to higher gas (carbon dioxide) production during fermentation, it is dueto increasing of monosaccharide (xylose) production by XY action. Also, this effect could be due to the action between xylose molecular and gluten network. Hydrolyzed starch or oligosaccharide producing by Am can be leads to increasing of loaf volume, which observed during the previous results. The addition ofAM during fermentation it stimulates the yeast to production of carbon dioxide (Gujral et al., 2003 and Kim et al., 2006). The addition of GO to commercial wheat flour positively influence the volume of pan bread and this effect was a linear with the increase in dose 
(Shafisoltani et al., 2014). GO could be led to increase the strength of dough and this is reflected on retaining the dough of gas therefore increasing of the bread specific volume.

Table 5. Specific volume of pan bread

\begin{tabular}{|c|c|c|c|c|c|c|c|c|c|c|}
\hline & \multicolumn{10}{|c|}{ Treatments } \\
\hline & Control & GO1 & GO2 & GO3 & XY1 & XY2 & XY3 & AM1 & AM2 & AM3 \\
\hline Weight(g) & 176.765 & 109 & 113.5 & $\mathbf{1 0 7 . 5}$ & 108.5 & 111.25 & 110.75 & 107.5 & 112.5 & 111.25 \\
\hline $\begin{array}{l}\text { Volume } \\
\left(\mathrm{cm}^{3}\right)\end{array}$ & 326.5 & 350 & 345 & 392.5 & 385 & 425 & 422.5 & 315 & 330 & 365 \\
\hline $\begin{array}{l}\text { Specific } \\
\text { volume } \\
\left(\mathrm{cm}^{3} / \mathrm{g}\right)\end{array}$ & $\begin{array}{c}2.06 \\
\pm 0.04^{\mathrm{e}}\end{array}$ & $\begin{array}{c}3.22 \\
\pm 0.08^{\text {cd }}\end{array}$ & $\begin{array}{c}3.05 \\
\pm 0.06^{d}\end{array}$ & $\begin{array}{c}3.65 \\
\pm 0.04^{\text {ab }}\end{array}$ & $\begin{array}{c}3.55 \\
\pm 0.00^{b}\end{array}$ & $\begin{array}{c}3.82 \\
\pm 0.08^{a}\end{array}$ & $\begin{array}{c}3.81 \\
\pm 0.01^{a}\end{array}$ & $\begin{array}{c}2.93 \\
\pm 0.02^{d}\end{array}$ & $\begin{array}{c}2.93 \\
\pm 0.03 \\
\end{array}$ & $\begin{array}{c}3.28 \\
\pm 0.03^{c}\end{array}$ \\
\hline
\end{tabular}

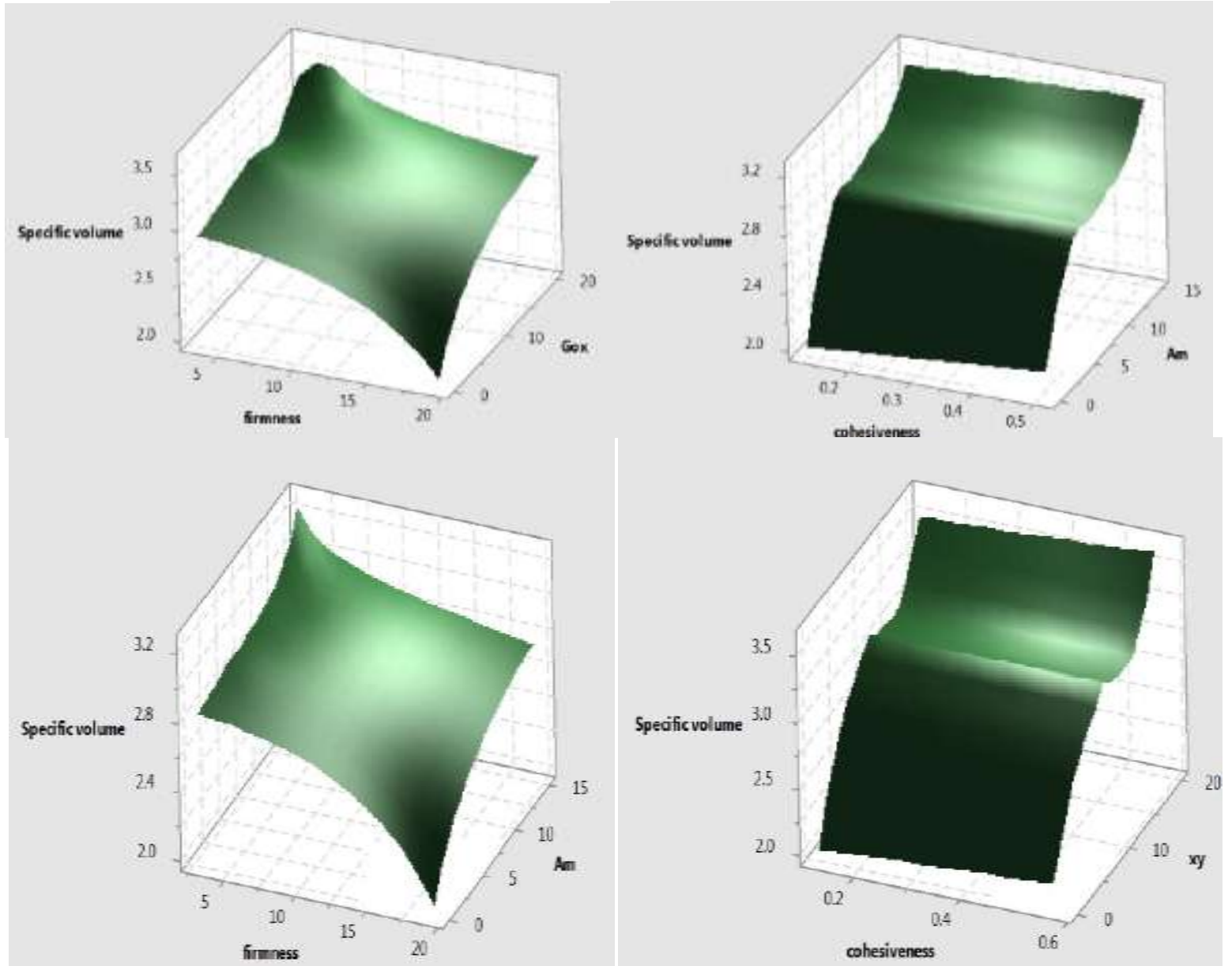

Fig.(4): Response surface plots of specific volume, firmness and Cohesiveness: GO, glucose oxidase; XY, xylanase; AM, $\alpha$ amylase.

Rheological properties of dough (alveogragh parameteres)

Rheological properties of commercial wheat flour dough containing the best doses of different enzymes are summarized in Table (6) and Fig(5). The addition of GO was due to increasing of the $\mathrm{P}(\mathrm{mm}$ $\mathrm{H}_{2} \mathrm{O}$ ) which mean the dough tenacity (aptitude to resist deformation), $\mathrm{W}(10-4 \mathrm{~J})$ which mean also the dough baking strength (surface under the curve) and $\mathrm{P} / \mathrm{L}$ that mean the configuration of the curve. But it's due to decreasing of the $\mathrm{L}(\mathrm{mm})$ dough extensibility (maximum volume of air that the bubble is able to contain) and $\mathrm{G}(\mathrm{mm})$ the index of swelling. On the contrary, it was with the control sample (Rasiah $\boldsymbol{e t}$ al., 2005;Decamps et al., 2012 andYang et al., 2014). The addition of both Am and $X Y$ was indicated midiate level between $\mathrm{GO}$ and control sample in all alveograpg parameters. Bonet et al. (2007)noted that the possibility of improving and rebuilding the gluten network of damaged wheat by GO treatments. This effect has been described by forming dityrosine crosslinks between the wheat 
proteins. Several studies indicate that there are some enzymes that are able to make an impact similar to GO such as Hexose Oxidase (HOX). The addition of HOX could be due to strength dough and bread characteristics. This is due to the oxidative reaction

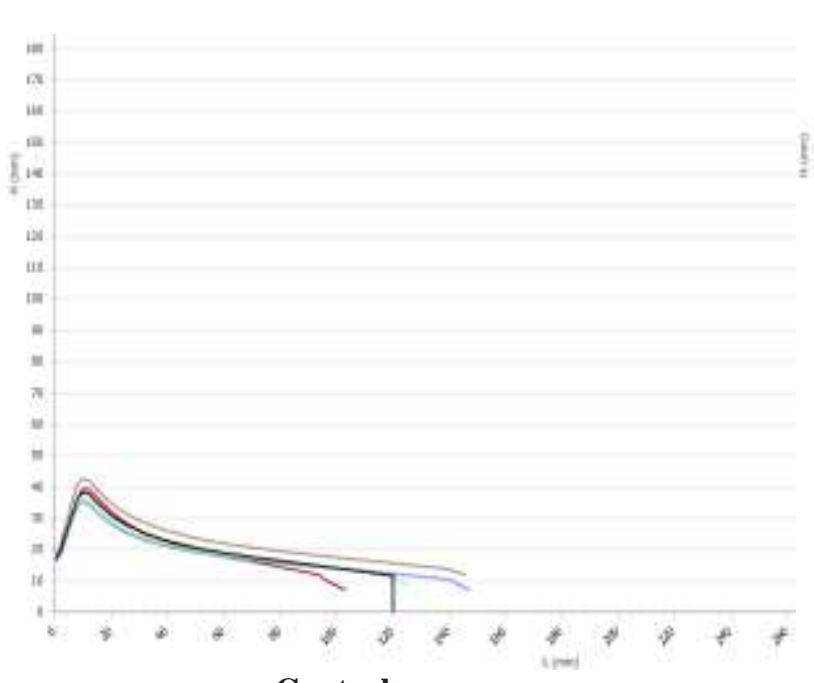

Control

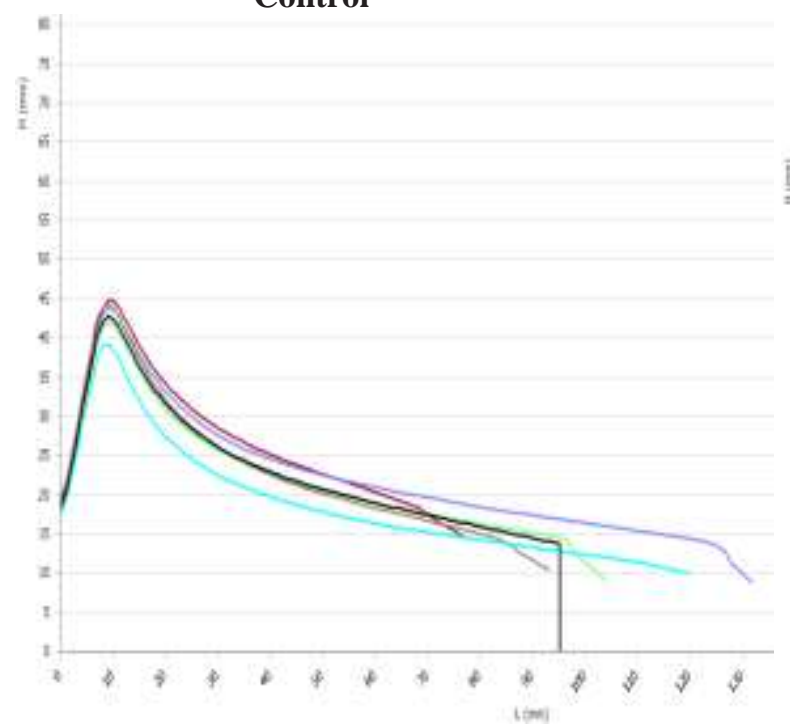

XY 3 for HOX. But, these results cannot be generalized for all wheat varieties as HOX affects the dough from different wheat varieties in different ways (GUL et al., 2009 and Maikweki et al., 2014).

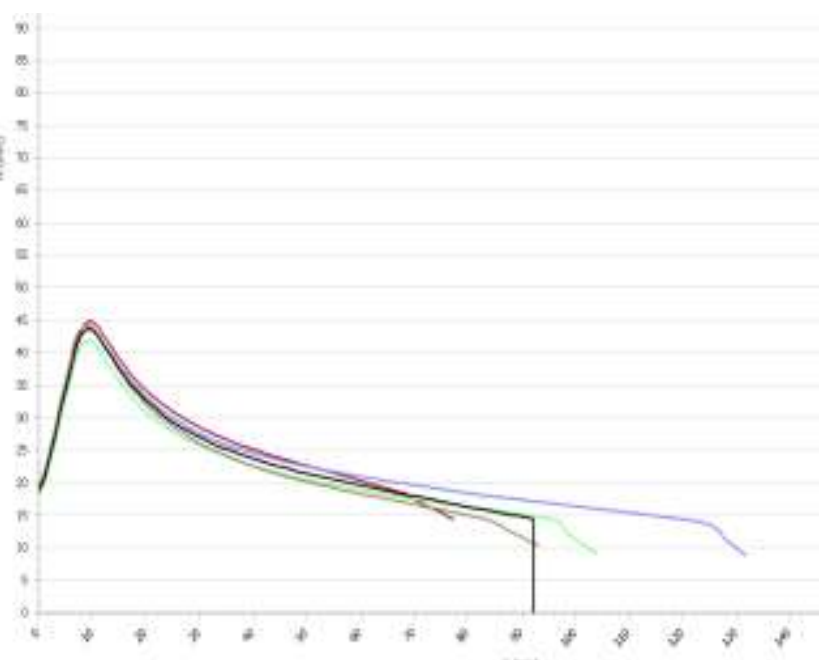

Am3

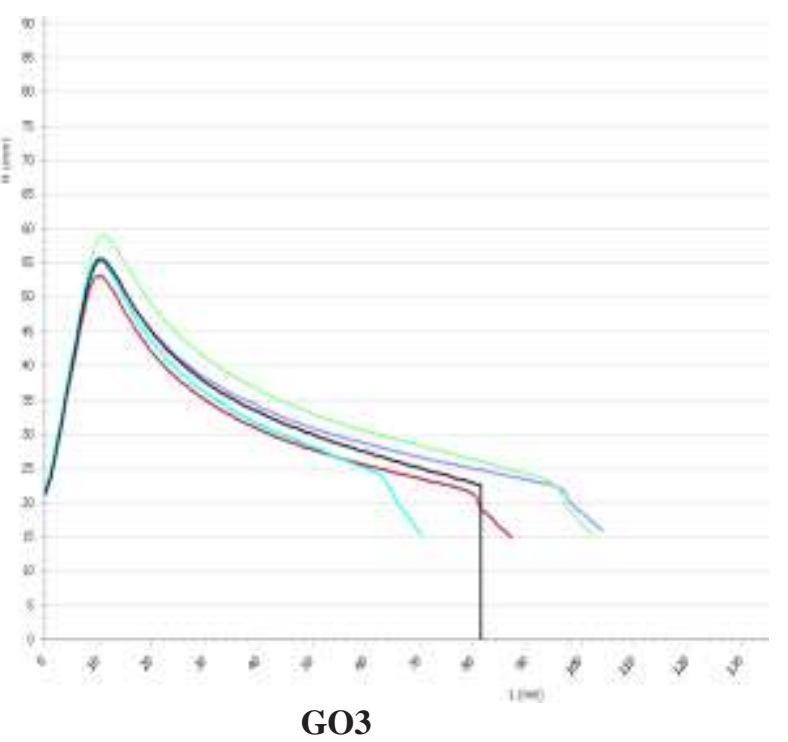

Fig.5.Curve Alveograph for the best treatments

Table 6. Alveograph parametersfor the best treatments

\begin{tabular}{lcccc}
\hline Parameter & Control & $\mathrm{A3}$ & $\mathrm{G3}$ & $\mathrm{X3}$ \\
\hline$P\left(\mathrm{~mm} \mathrm{H} \mathrm{H}_{2} \mathrm{O}\right)$ & 42.0 & 48.0 & $\mathbf{6 1 . 0}$ & $\mathbf{4 7 . 0}$ \\
$L(\mathrm{~mm})$ & 120.0 & 91.0 & $\mathbf{8 1 . 0}$ & 95.0 \\
$G(\mathrm{~mm})$ & 24.3 & 21.2 & $\mathbf{2 0 . 0}$ & 21.6 \\
$W(10-4 \mathrm{~J})$ & 164.0 & 148.0 & $\mathbf{1 8 4 . 0}$ & $\mathbf{1 4 6 . 0}$ \\
$P / L$ & 0.35 & 0.53 & 0.75 & 0.49 \\
$I e(\%)$ & 60.3 & 55.1 & 60.6 & 54.4 \\
\hline
\end{tabular}

\section{Conclusion}

The supplementation of the Egyptiancommercial flour (extract 82\%) showed a significant improvement each of the properties. Specificvolume has increased with every treatment, though it the XY treatment was a highly effective. But the AM treatment was a lower effective, while the GO treatment was a among of them. Alkaline water retention capacity,improved with add all of the treatments. Despite the contrast level of improvement 
between different enzymes and between the doses of the same enzyme. Add enzymes showed a noticeable positive change in the rheologicale properties. All of these changes culminated in the sensory evaluation, which showed a significant approbation for treatments compared with the control sample.

\section{References}

A.A.C.C.(2000). American Association for Cereal chemistry. 10 ${ }^{\text {th }}$ Edition. AACC international, St. paul. MN.

A.O.A.C. (2000). Official Methods of Analysis of Association of Official Analytical Chemists. 17th Ed. By Horwitz, W. Suite 500, 481 Norh Fredric avenueGaithersburg, Maryland20877-2417, USA.

Ahmad, Z.; Butt, M. S.; Ahmed, A. and Khalid, N. (2013). Xylanolytic modification in wheat flour and its effect on dough rheological characteristics and bread quality attributes. Journal of the Korean Society for Applied Biological Chemistry, 56: 723-729.

Ahmad, Z.; Butt, M. S.; Ahmed, A.; Riaz, M.; Sabir, S. M.; Farooq, U. and Rehman, F. U. (2014). Effect of Aspergillus niger xylanase on dough characteristics and bread quality attributes. Journal of Food Science and Technology,51: 2445-2453.

Aja, S.; Wang, J. and Rosell, C. (2003). Improvement of cereal protein network through enzyme treatment. Caracterizacion, deteccion y mejora de los trigos atacados por heterópteros, 95: 101-106.

Ball, S. G. and Morell, M. K. (2003). From bacterial glycogen to starch: understanding the biogenesis of the plant starch granule. Annual review of plant biology, 54: 207-233.

Bankar, S. B.; Bule, M. V.; Singhal, R. S. and Ananthanarayan, L. (2009). Glucose oxidase An overview. Biotechnology Advances, 27: 489501.

Bell, A. E. (1990). The alveograph handbook. Food Chemistry,37- 77.

Bonet, A.; Rosell, C. M.; Caballero, P. A.; Gomez, M.; Perez-Munuera, I. and Lluch, M. A. (2006). Glucose oxidase effect on dough rheology and bread quality: A study from macroscopic to molecular level. Food Chemistry,99: 408-415.

Bonet, A.; Rosell, C. M.; Perez-Munuera, I. and Hernando, I. (2007). Rebuilding gluten network of damaged wheat by means of glucose oxidase treatment. Journal of the Science of Food and Agriculture,87, 1301-1307.

Caballero, P. A.; Gomez, M. and Rosell, C. M. (2007). Improvement of dough rheology, bread quality and bread shelf-life by enzymes combination. Journal of Food Engineering,81: 42-53.

Collins, T.; Hoyoux, A.; Dutron, A.; Georis, J.; Genot, B.; Dauvrin, T.; Arnaut, F.; Gerday, C. and Feller, G. (2006). Use of glycoside hydrolase family 8 xylanases in baking. Journal of Cereal Science, 43: 79-84.

Dagdelen, A. F. and Gocmen, D. (2007). Effects of glucose oxidase, hemicellulase and ascorbic acid on dough and bread quality. Journal of Food Quality, 30: 1009-1022.

Decamps, K.; Joye, I. J.; Courtin, C. M.and Delcour, J. A. (2012). Glucose and pyranose oxidase improve bread dough stability. Journal of Cereal Science, 55: 380-384.

Driss, D.; Bhiri, F.; Siela, M.; Bessess, S.; Chaabouni, S. and Ghorbel, R. (2013). Improvement of breadmaking quality by xylanase gh11 from Penicillium occitanis PO16. Journal of Texture Studies, 44:75-84.

Dunnewind, B.; van Vliet, T. and Orsel, R. (2002). Effect of Oxidative Enzymes on Bulk Rheological Properties of Wheat Flour Doughs. Journal of Cereal Science,36: 357-366.

Giannone, V.; Lauro, M. R.; Spina, A.; Pasqualone, A.; Auditore, L.; Puglisi, I. and Puglisi, G. (2016). A novel $\alpha$-amylase-lipase formulation as anti-staling agent in durum wheat bread. LWTFood Science and Technology, 65:381-389.

Gujral, H. S.; Guardiola, I.; Carbonell, J. V. and Rosell, C. M. (2003). Effect of cyclodextrin glycosyl transferase on dough rheology and bread quality from rice flour. Journal of agricultural and food chemistry,51: 4846-4846.

GUL, H.; OZER, M. S. and Dizlek, H. (2009). Improvement of the wheat and corn bran bread quality by using glucose oxidase and hexose oxidase. Journal of Food Quality,32: 209-223.

Indrani, D.; Manohar, R. S.; Rajiv, J. and Rao, G. V. (2007). Alveograph as a tool to assess the quality characteristics of wheat flour for parotta making. Journal of Food Engineering,78: 1202-1206.

Jaekel, L. Z.; Silva, C. B. d.; Steel, C. J. and Chang, Y. K. (2012). Influence of xylanase addition on the characteristics of loaf bread prepared with white flour or whole grain wheat flour. Food Science and Technology (Campinas), 32: 844849.

Katina, K.; Salmenkallio-Marttila, M.; Partanen, R.; Forssell, P. and Autio, K. (2006). Effects of sourdough and enzymes on staling of high-fibre wheat bread. LWT - Food Science and Technology,39: 479-491.

Kim, J. H.; Maeda, T. and Morita, N. (2006). Effect of fungal $\alpha$-amylase on the dough properties and bread quality of wheat flour substituted with polished flours. Food Research International, 39: 117-126.

Kitterman, J. and Rubenthaler, G. (1971). Application of the Brookfield viscometer for measuring the apparent viscosity of acidulated flour-water suspensions. Cereal science today.http://www.nal.usda.gov/ 
Leon, A. E.; Duran, E. and Benedito de Barber, C. (2002). Utilization of enzyme mixtures to retard bread crumb firming. Journal of agricultural and food chemistry, 50: 1416-1419.

Maikweki, N. M.; Shitandi, A.; Faraj, A. and Bitonga, R. O. (2014). Evaluation of the Effect of Hexose Oxidase on the Bread Baking Properties of Flour from Three Kenyan Wheat Varieties. International Journal of Science and Research, 3: 2319-7064.

Majzlova, K.; Pukajova, Z. and Janecek, S. (2013). Tracing the evolution of the $\alpha$-amylase subfamily GH13_36 covering the amylolytic enzymes intermediate between oligo-1, 6-glucosidases and neopullulanases. Carbohydrate research,367: 4857.

Mariotti, M.; Pagani, M. A. and Lucisano, M. (2013). The role of buckwheat and HPMC on the breadmaking properties of some commercial gluten-free bread mixtures. Food Hydrocolloids, 30: 393-400.

Pyler, E. (1988). Keeping properties of bread. Baking science and technology, 2: 815-849.

Rasiah, I.; Sutton, K.; Low, F., Lin, H.-M. and Gerrard, J. (2005). Crosslinking of wheat dough proteins by glucose oxidase and the resulting effects on bread and croissants. Food Chemistry, 89: 325-332.

Sangnark, A. and Noomhorm, A. (2004). Chemical, physical and baking properties of dietary fiber prepared from rice straw. Food Research International,37: 66-74.

Shafisoltani, M.; Salehifar, M. and Hashemi, M. (2014). Effects of enzymatic treatment using
Response Surface Methodology on the quality of bread flour. Food Chemistry, 148: 176-183.

Shah, A. R.; Shah, R. and Madamwar, D. (2006). Improvement of the quality of whole wheat bread by supplementation of xylanase from Aspergillus foetidus. Bioresource technology,97: 2047-2053.

Smith, J. P.; Daifas, D. P.; El-Khoury, W.; Koukoutsis, J. and El-Khoury, A. (2004). Shelf life and safety concerns of bakery products-a review. Critical Reviews in Food Science and Nutrition,44:19-55.

Steel, R.; Torrie, J. and Dickey, D. (1997): Principles and procedures of Statistics: A Biometrical Approach, $3^{\text {rd }}$ ed., McGraw-Hill, New York, NY.

Steffolani, M. E.; Ribotta, P. D.; Perez, G. T. and Leon, A. E. (2010). Effect of glucose oxidase, transglutaminase, and pentosanase on wheat proteins: Relationship with dough properties and bread-making quality. Journal of Cereal Science, 51: 366-373.

Yamazaki, W. (1953). An alkaline water retention capacity test for the evaluation of cookie baking potentialities of soft winter wheat flours. Cereal Chemistry, 30: 242-246.

Yang, T.; Bai, Y.; Wu, F.; Yang, N.; Zhang, Y.; Bashari, M.; Jin, Z. and Xu, X. (2014). Combined effects of glucose oxidase, papain and xylanase on browning inhibition and characteristics of fresh whole wheat dough. Journal of Cereal Science, 60: 249-254.

Yaseen, A. A.; Shouk, A. and Ramadan, M. T. (2010). Corn-wheat pan bread quality as affected by hydrocolloids. Journal of American Science, 6:684-690. 


\section{تأثير أستخدام الإنزيمات على جودة خبز القوالبالمصنوع من دقيق القمح المصري}

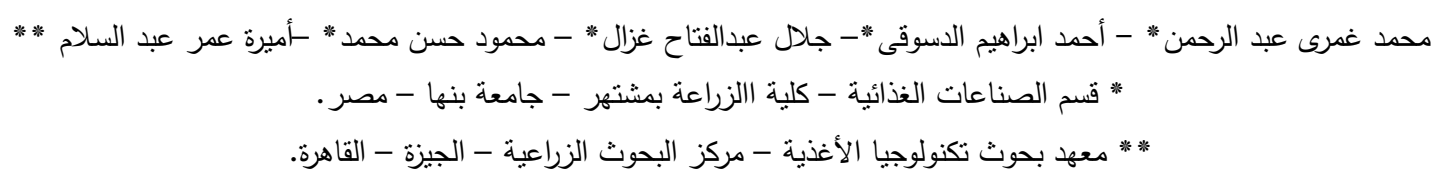

الملخص العربى

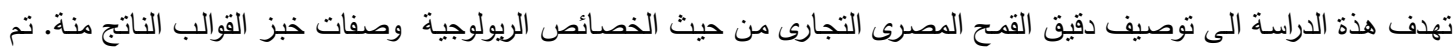

استخدام ثلاثة من الانزيمات وهم الجلوكوز اوكسيديز و الالفا اميليز والزيلينيز وكانت التركيزات كما يلى: الجلوكوز اوكسيديز كان 10و 10 15و

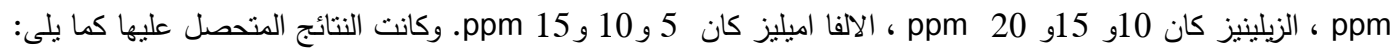

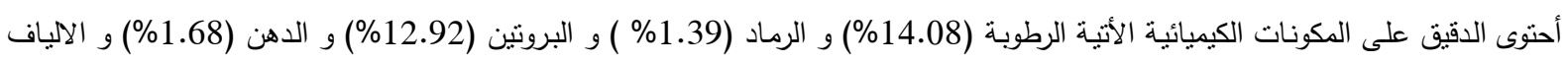
(2.36\%) و الكربوهيدرات (67.39 \%) و الجلوتين الرطب(28.6\%) اما الجلوتين الجاف فكان (11.2\%). اوضحت نتائج التحليل الكيماوى

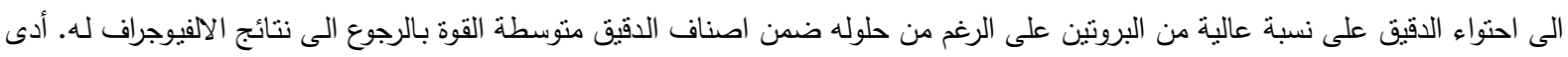

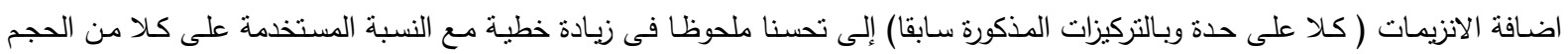
النوعى للخبز و خصائص القوام ودرجة وقدرة المنتج على مسك الماء. حقق انزيم الزيلينيز اعلى المستويات فى قدرة الخبز الناتج على الاحتفاظ

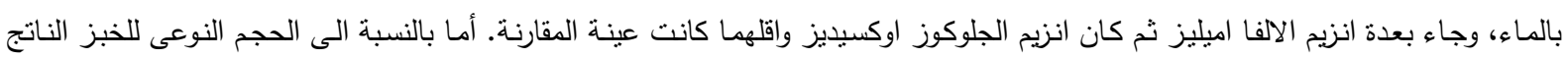

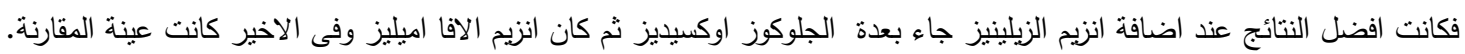

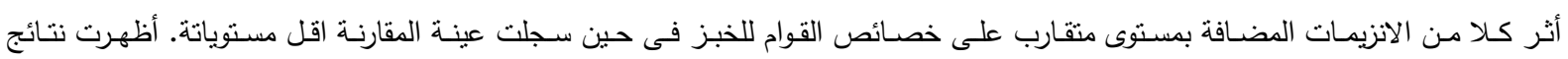
الالفيوجراف التى أجريت لافضل الجرعات من الانزيمات الثلاثة افضلية انزيم الجلوكوز اوكسيديز عند مستوى ppm 20 عن كلا من انزيم الالفا اميليز والزيلينيز بينما أظهرت عينة المقارنة أقل القيم. 